\title{
Protein phosphorylation pathways disruption by pesticides
}

\author{
Gladis Magnarelli, ${ }^{1,2}$, Teresa Fonovich ${ }^{3}$ \\ ${ }^{1}$ Instituto Multidisciplinario de Investigación y Desarrollo de la Patagonia Norte (IDEPA), Consejo Nacional de Investigaciones \\ Científicas y Técnicas (CONICET), Universidad Nacional del Comahue, Neuquén, Argentina \\ ${ }^{2}$ Facultad de Ciencias Médicas, Universidad Nacional del Comahue, Cipolletti, Argentina \\ ${ }^{3}$ Escuela de Ciencia y Tecnología, Universidad Nacional de San Martín, Buenos Aires, Argentina \\ Email: ggmagnarelli@yahoo.com.ar
}

Received 26 July 2013; revised 26 August 2013; accepted 15 September 2013

Copyright (C) 2013 Gladis Magnarelli, Teresa Fonovich. This is an open access article distributed under the Creative Commons Attribution License, which permits unrestricted use, distribution, and reproduction in any medium, provided the original work is properly cited.

\begin{abstract}
Phosphosites in the human proteome represent an excellent source of potential biomarkers of pesticide toxicity. In fact, experimental animal models as well as in vitro studies have revealed phosphorylation disruption associated to metabolic regulation, hormone signaling, neuronal function and differentiation, cell survival and death. Due to their estrogen-mimicking ability, pesticides are considered as prime etiological suspects of increasing tumor incidence. Evidences of alterations in the signal transduction pathways involved in the tumor progression stage of pesticides were also provided. Despite progress in understanding the effect of pesticides on the human phosphoproteome and their health outcomes, it remains a complex issue to be studied. By now, the potential impact of pesticides in epigenetic phosphorylation pathways remains poorly explored. In addition, studies involving pesticides mixtures effects are needed. This review updates and provides a comprehensive discussion on the molecular and biochemical events underlying protein phosphorylation pathway disruption caused by pesticides most frequently detected in human tissues and fluids, such as organochlorine pesticides and organophosphates. The link between epidemiological studies and experimental approaches is also considered. Future challenges, such as microarray phosphoproteome studies to complement gene expression arrays to understand the mechanisms involved in pesticide toxicology are briefly discussed.
\end{abstract}

Keywords: Protein Phosphorylation; Organochlorine Pesticides; Organophosphate Pesticides; Kinases

\section{INTRODUCTION}

Pesticides comprise a heterogeneous group of chemicals which are considered as one of the main factors involved in environmental contamination of today's world. These compounds comprise among more than 1000 active ingredients that are marketed as insecticide, herbicide, and fungicide [1]. Over $98 \%$ of sprayed insecticides and $95 \%$ of applied herbicides reach a destination other than their targeted species, including air, water, bottom sediments, food and non-target living systems. These toxic chemicals designed to act as poison to the pests are able to produce devastating effects on intoxicating nontarget organisms, including humans [2]. Organochlorine pesticides (OC) are the persistent environmental contaminants. Commercial-grade DDT (bis[4-chlorophenyl]-1, 1,1-trichloroethane) is among the most ubiquitous pesticides used, in the history of these compounds [3]. Use and production of many OC were banned in most developed countries. Only a few active substances are still in use, for example DDT continues to be applied in tropical countries to control malaria vectors, through indoor residual spraying $[4,5]$ and lindane for treatment of lice and scabies [6]. However, the general population is still exposed to them, due to their high persistence in the environment.

Since OC are the most lipophilic pesticides in nature and have long half lives between months to years, they tend to accumulate in adipose tissues and biomagnify through the food chain creating a persistent exposure risk to human [7]. Classical effects involved the induction of hyperexcitable state in central and peripheral nervous system by disruption of normal flow of sodium and potassium across the axon membrane as well as by antagonization of GABA (gamma-aminobutyric acid)-mediated 
inhibition in CNS [8].

One of the most important classes of chemicals actively applied to the environment consists of a group of cholinesterase-inhibiting compounds usually called organophosphates (OP). These pesticides are often preferred because of their higher biodegradability and low cost of manufacture [9]. Their bioactivation products, consisting on the oxon forms of them, inhibit acetylcholinesterase by irreversible phosphorylation of its active site, leading to an excess of acetylcholine accumulation at the nerve endings [8]. Almost every person is or has been exposed to OP insecticides at home, at his workplace or because of environmental contamination [10, 11]. Living next to pesticide treated areas, or in agricultural regions, highly contributes to human exposure, but domestic contribution (house and yard pesticides application) must not be disregarded. Ingestion of residues in the diet or through secondary ingestion of contaminated house dust/soil, or hand-to-mouth contact, via inhalation of vapors or dermal absorption following contact with the skin may represent other entries [12].

In the last decade, public concern over potential adverse health effects of pesticides has focused on a number of chronic end points such as endocrine disruption, carcinogenesis, immunological and reproductive effects as well as cognitive and behavioral effects. In regards to epidemiological studies, cautious interpretation is warranted. The major limitation of these studies is the fact that exposure has mostly been assessed based on questionnaires and that humans are exposed not only to mixtures of pesticides but also to other pollutants. As described below, experimental studies support the hypotesis that OC and OP impair phosphorylation pathways are involved in these adverse health effects.

\section{EFFECTS OF PESTICIDES ON PROTEIN PHOSPHORYLATION PATHWAYS}

Reversible phosphorylation and dephosphorylation of proteins catalyzed by protein kinases and protein phosphatases respectively, is one of the most important and widespread molecular regulatory mechanisms. It controls almost all aspects of cellular physiology, including proliferation, division, differentiation, adherence, angiogenesis and apoptosis [13].

Based upon the nature of the phosphorylated $\mathrm{OH}$ group, these proteins are classified as protein-serine/ threonine kinases (385 members), protein-tyrosine kinases (90 members), and tyrosine-kinase like proteins (43 members) [14]. Phosphorylation and dephosphorylation at serine, threonine or tyrosine residues may induce allosteric conformational changes in phosphoproteins, which might evoke alterations in protein enzymatic activity, stability, protein-protein interactions, transport and subcellular localization among other protein properties. The biological importance and clinical significance of protein phosphorylation is manifested by the implication of deregulation of both protein kinase and phosphatases activities in over 400 human diseases including cancer, diabetes, autoimmune and neurodegenerative diseases [13].

\subsection{Disruption of Hormone Signaling Pathways}

Pesticides also belong to the high heterogeneous group of molecules identified as endocrine disruptors (EDs). Recently, the first Scientific Statement of The Endocrine Society focused on a demanding need to understand the basic mechanisms of action and the physiological consequences of different EDs [15]. When present in the body, EDs may interfere at several control points in the hormone signaling pathways. As a result, the response cascade of natural hormones can either be inhibited or excessively enhanced, at the wrong time, in the wrong tissue [16]. Moreover, there is sufficient evidence to support the notion that at least some of the actions of EDs on developmentally-important genes and associated processes are epigenetic in nature and there is also evidence of epigenetic transgenerational transmission of these effects [17].

It was well established that OCs are EDs. Studies exploring OC as EDs have largely been focused on the genomic pathways. Endocrine activity of OC can be the result of direct binding with hormone receptors, due to their conformational similarity with the receptor-binding portions of natural hormones. The o,p'-DDT is the most estrogenic component of the DDT complex while the p,p'-DDE (dichlorodiphenyldichloroethylene) isomer is anti-androgenic by inhibitory binding to androgen receptor (AR) [18].

Research has shown that there are other signaling mechanisms for steroid hormones involving mitogenactivated protein kinases (MAPKs) pathways and G protein-coupled receptors. Mounting evidence suggests estrogen mimics can also act by these pathways, which work outside the nucleus [19]. MAPKs, including extracellular-signal-regulated kinases (ERKs), play central roles in controlling such diverse cellular outcomes as cell proliferation, apoptosis, and maturation. Many different stimuli, including steroids, growth factors, cytokines, ligands for G-protein - coupled receptors, and carcinogens, can activate the ERK pathways. ERKs can therefore serve as signal integrators for all of these inputs [14], so that the cell can render a final decision about its overall destiny (cell division, differentiation, death, or malignant transformation). The contribution of physiologic estrogens to this signaling mixture, integrated by MAPKs, can also be influenced by xenoestrogens [20]. In fact, OC have been reported to increase ERK1/2, a 
pathway mainly activated in response to mitogens and growth factors [21] and Akt phosphorylation by activating the estrogen receptor (ER) in cell lines $[22,23]$.

Numerous studies have proposed the ever-disturbing results of EDs as responsible for the decline in male and female fertility. However, potential risk to human is not easily answered because of the contradictory epidemicologic results regarding the controversial relationships of serum DDT levels and human reproductive disorders. Interestingly, Liu et al. [24] reported that very low doses of o,p'-DDT (picomolar or nanomolar, as the current range exposure levels of o,p'-DDT observed in the population) suppressed the expression of ovarian genes and production of prostaglandin E2 (PGE2). The use of receptor inhibitors showed that these inhibitory effects were exerted independently of either classical ERs or G protein coupled receptor 30 (GPR30). Instead, o,p'-DDT altered gene expression or hormone action via inhibiting the activation of PKA (protein kinase A), through direct interference with its catalytic subunit thus leading to disruption in ovarian processes.

Epidemiological evidence exists about relations between maternal exposure to OC and pregnancy outcomes $[25,26]$. The ability of trophoblast to differentiate and fuse into a multinucleate syncytium and acquire an active endocrine phenotype is under the control of a plethora of hormonal signals. Studies in choriocarcinoma cellular models as well as primary villous trophoblasts and placental explants, established the important role of the cAMP/PKA and MAPK cascades in these processes. Delidaki et al. [27] have recently proposed signaling "cross-talk" between cAMP/PKA ERK1/2 and p38MAPK in the regulation of genes that are relevant for BeWo trophoblast differentiation and hormone genesis. A rise in intracellular cAMP levels through activation of the adenylyl cyclase pathway leads to PKA activation and interactions with AKAPs and downstream phosphorylation of ERK1/2 and p38MAPK. PKA and ERK1/2-dependent mechanisms activate CREB-1/ATF-1 to increase hCG production. A role of PKA in the syncytiotrophoblast mitochondria associated with progesterone synthesis was also described [28]. Interestingly, we found that incubations with o,p'-DDT of placental villi homogenates produced an eight-fold increase on PKA activity from the particulate fraction and increased phospholabeling in mitochondria $65-\mathrm{kDa}$ and $24-\mathrm{kDa}$ phosphoprotein bands [29]. In line with these findings, it was reported that PKA modulates the mitochondrial protein phosphorylation cycle [30]. Although the understanding of the potential consequences in the physiopathology of the placenta requires additional research, our results suggest that o,p'DDT may potentially affect progesterone and hCG production and increase the risk of placental disorders due to an altered trophoblast function or differentiation [31].
These controversial findings on PKA activity of the in vitro studies cited above may be explained by the prooxidant conditions produced by o,p'-DDT in the studied systems. It is well known that increased oxidative stress (see item 2.6) is a second biological effect caused by OC and that the sensitivities of PKA isoforms to radicals may be different, depending upon the type of ROS produced and antioxidant systems present, which are tissue-dependent [32].

Chlorpyrifos, one of the most widely used OP in the world, was recognized as an ED since it has been demonstrated to possess the ability to interfere with the ER mRNA steady state levels [33] and to induce cell proliferation through ER $\alpha$ in hormone-dependent breast cancer cells [34]. Some OPs also exhibit in vitro AR antagonism $[35,36]$. However, there is a lack of information about the OP impact on the protein phosphorylation pathways potentially involved in those effects.

\subsection{Effects on Neuronal Function and Differentiation Pathways}

Besides its reproductive function, estradiol (E2) is also an important factor in the brain, where it has several functions such as memory enhancement, neuritegenesis and neuroprotection, as well as a role in reproductive behavior [37,38]. Within the cerebellum, E2 signaling has a role in cerebellar development and the modulation of synaptic neurotransmission in the adult [39]. Among the non genomic effects of E2, the activation of MAPK and PI3K/Akt pathways has been shown to be crucial in most of the neuronal functions regulated by estrogens. Aside from its major roles on intracellular proliferation and differentiation, ERK1/2 in the central nervous system plays a variety of roles in neuronal survival or death, synaptic plasticity, learning and memory through phosphorylation of various substrates such as transcription factors, cytoskeletal proteins, regulatory enzymes and kinases in post mitotic neurons. A number of classical studies using neuronal cultures showed that ERK $1 / 2$ is activated in response to excitatory glutamatergic stimulation followed by $\mathrm{Ca}^{+2}$-influx into neurons [40]. $\mathrm{PKC}$ is a collecting point for expression of the genes encoding the neurotrophic factors and has a key role in neuritic outgrowth and synapsis. PKC is a superfamily of serine-threonine kinases structurally correlated, that catalyze numerous biochemical reactions that are critical to cellular functions. Currently, the PKC family incorporates twelve isoforms, which can be classified into three subfamilies related through their primary structure and on their requirement of specific activators [41]. Also, CREB phosphorylation constitutes a convergence point for many signaling cascades, playing a pivotal role in neuronal development, synaptic plasticity, memory func- 
tion, regeneration, and cell survival in response to various types of stress [42]. As shown in Figure 1, these crucial pathways might be disrupted by in vitro and in vivo pesticide exposure, as described below.

OC interference with non genomic ER actions mediated by phosphorylation pathways involved in synaptic plasticity and synaptogenesis was reported. Briz et al. [43] showed that OC have estrogenic effects in primary cultures of cerebellar granule cells and cortical neurons through interaction with neuronal ERs. Dieldrin and endosulfan increased Akt phosphorylation in cortical neurons, which was inhibited by an ER $\beta$ antagonist. Instead, Akt and ERK1/2 phosphorylation induced by dieldrin in cerebellar granule cells was mediated by multiple activetion of $\mathrm{ER} \alpha, \mathrm{ER} \beta$, and $\mathrm{G}$ protein-coupled receptor 30. Lindane did not activate these pathways but inhibited E2-mediated Akt and ERK1/2 activation. Although the pesticides used in these experiments belong to the $\mathrm{OC}$ family, they have different chemical structures. Endosulfan and dieldrin are cyclodiens while lindane is a cyclohexane derivative. Different molecular interactions between OC and the hormone receptors, as well as pesticide incorporation in biomembranes with consequent alteration in their physicochemical properties, might explain the differences observed on their effects. ERK1/2 signaling pathway was also activated in primary cultures of cortical neurons by dieldrin, and lindane through a mechanism involving $\mathrm{GABA}_{\mathrm{A}}$ and glutamate receptors. Interestingly, elevated levels of dieldrin and lindane $[44,45]$ were found postmortem in the brain of Parkinson disease (PD) patients. Moreover, signaling pathways downstream of MAP, are particularly important in PD. Notably, ERK plays a key role in cross-talk between two dominant PD genes [46].

Several reports provide evidence that OP compounds can modulate important signal transduction pathways in the CNS, through induction of ERK and JNK phosphorylation via PKC in rat brain cells [47], as well as the cyclic AMP-responsive element-binding protein (CREB) phosphorylation in cultured neurons [48].

In addition, Slotkin et al. [49] compared the direct effects of chlorpyrifos and diazinon using treatment protocols devoid of cytotoxicity on the expression of PKC isoforms and PKC regulators in PC12 cells. This model for neuronal development, unlike primary neurons, maintains their ability to divide in culture and to differentiate into specific phenotypes, in a coordinated way. Chlorpyrifos evoked by far the largest effects on the expression of genes encoding PKC isoforms and modulators of

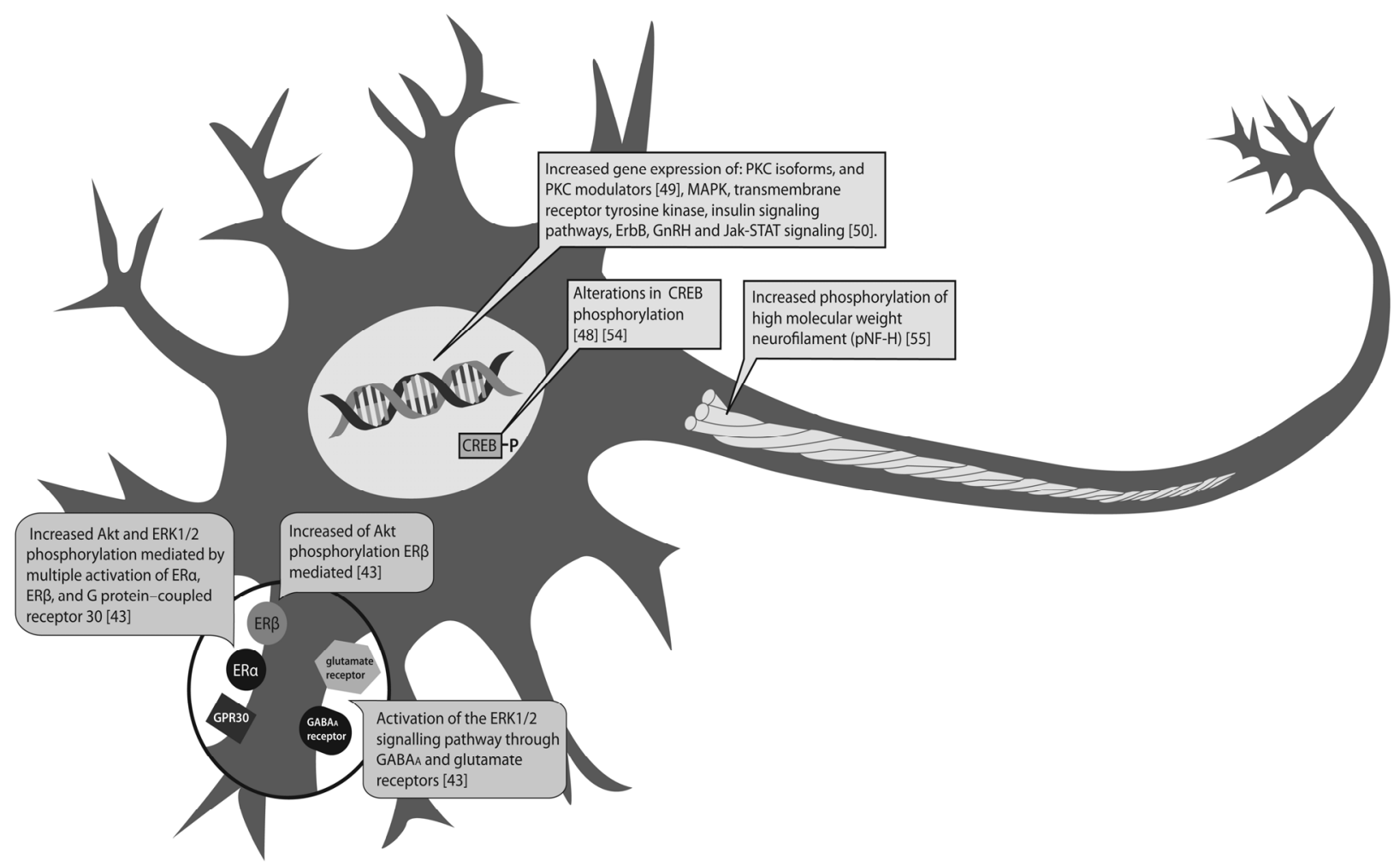

Figure 1. Neuronal phosphorylation pathways and phosphoproteins targets of pesticides. OC interference with nongenomic ER, $\mathrm{G}$ protein-coupled receptor $30, \mathrm{GABA}_{\mathrm{A}}$ and glutamate receptors actions mediated by phosphorylation pathways (dark grey boxes). OP effects on phosphoprotein levels and expression of genes involved in signal transduction pathways (light gray boxes). CREB: cyclic AMP-responsive element-binding protein, ER: estrogen receptor, $\mathrm{GABA}_{\mathrm{A}}$ : $\gamma$-aminobutyric acid, GnRH gonadotropin-releasing hormone, MAPK: mitogen-activated protein kinases, PKC: protein kinase C. 
PKC activity, thus reflecting a similar target on PKC signaling than the one evoked by chlorpyrifos in vivo in the developing rat brain. In contrast to the robust effects of chlorpyrifos in differentiating PC12 cells, diazinon affected a more restricted repertoire of genes.

Moreira et al. [50] applied microarray technology to explore in depth the dose-dependent alterations in transcriptional response both in the maternal and fetal brains after gestational exposure of mouse to chlorpyrifos (gestational days 6 to 17). Interestingly, the dose-effect relationship of chlorpyrifos on gene expression, both at the gene and pathway levels was not necessarily related to brain acetylcholinesterase inhibition. In regards to phosphorylation pathways, in the fetal brain, MAPK, transmembrane receptor tyrosine kinase and insulin signaling pathways, were identified to be enriched. Pathways found to be up-regulated in the maternal brain included ErbB signaling pathway, GnRH signaling pathway and Jak-STAT signaling pathway. Further studies are required to elucidate whether these alterations in gene expression reflect alterations in the phosphoproteome.

Humans exposed to low levels of OP agents have reported difficulty in concentration as well as memory impairment, long after the exposure has ceased [51,52]. Experimental observations in exposed rats demonstrated that low-level exposure to OPs impaired their cognitive functions without a significant effect on acetylcholinesterase activity [53,54]. Vermas et al. [54] investigated the mechanism underlying these effects in rats treated with dichlorvos and showed that adenylyl cyclase, a downstream target of M2 signaling and cAMP levels, were significantly decreased. Moreover, the phosphorylation of CREB, was significantly reduced. Considering that CREB is a memory enhancing transcription factor, these authors suggest that reduced phosphorylation of CREB by dichlorvos exposure may contribute to the neurobehavioral deficits that have been described.

As cytoskeleton is one of the most important targets of neurotoxic chemicals, it was proposed that long-lasting neurotoxicity may modify proteins involved in axonal transport. It was reported protein oxidative damage, increased calpain expression and phosphorylation of the high molecular weight neurofilament subunit, along with decreased alpha tubulin levels in intoxicated rat brain after nerve agent poisoning. Calpains are known to regulate the activities of several protein kinases and phosphatases that modify cytoskeleton, in addition to cleaving diverse cellular substrates including cytoskeletal proteins [55].

\subsection{Effects on Signalling Pathways in Tumor Development}

Cancer development is a complex process during which a normal cell undergoes a progressive series of alterations resulting in the acquisition of an altered proliferative capacity, invasiveness and metastatic potential. These alterations are classically defined as occurring in stages: initiation involves DNA damage leading to mutation(s); then follows promotion, which involves enhanced proliferation and altered cell behavior and finally progression, which results from subsequent genetic changes such as loss of heterozygosity and gene amplification [56].

Angiogenesis contributes to tumor progression. In this sense, it is well stated that the vascular endothelial growth factor (VEGF) expression allows for more aggressive tumor growth [57]. Due to their estrogen-mimicking ability, pesticides are considered as prime etiological suspects of increasing tumor incidence, although a direct link is still undefined [58]. Besides epidemicologic studies, lines of evidence strongly suggest that OC and OP can cause malignant transformation of cells both in in vitro and in vivo models $[59,60]$. However, further work is required to fully explore the exact mechanisms by which pesticide exposure affects the integrity and normal function of oncogenes and tumor suppressor genes in humans [60].

Pesticides can also affect promotion stage. As the RasRaf-MEK-ERK pathway is up regulated in a variety of cancers even in the absence of oncogenic mutations, it was investigated as a target of pesticides toxicity. Altered expression of PKC isoenzymes has also been observed in a number of human cancers. While most studies report down-regulated expression of PKC $\alpha, \beta$ and $\delta$ in human cancers, PKC $\varepsilon, \mathrm{PKC} \alpha$ and $\delta$ have often been found to be over expressed in various cancers relative to the normal tissue $[56,61]$.

In an extensive review Mrema [62] have described the mechanisms associated to in vitro and in vivo OC proliferative effects such as c-Src kinase; ERK1/2 and ER $\alpha$ mediated phosphorylation. Occupational [63] and environmental human pesticide exposure [64] have been linked to prostate cancer. In line with these reports, in vitro studies with the human prostate cancer cell lines LNCaP and PC-3, showed that erbB-2 kinase, a recognized mitotic signaling protein, was activated by several OCs: $\beta$-hexa-chlorocyclohexane $(\beta-\mathrm{HCH})$ and o,p'-DDT as well as by heptachlor epoxide, a metabolite of heptachlor. Also, o,p'-DDT causes phosphorylation of MAPK and cellular proliferation of the androgen-dependent LNCaP line. However, no proliferative effect was observed in the androgen-independent PC-3 line. The proliferative effect of o,p'-DDT in LNCaP could not be blocked by the androgen receptor antagonist p,p'-DDE, indicating that this effect does not occur through direct interaction with the AR [65].

Further insight into the signal transduction pathways 
involved in the carcinogenic effects of o,p'-DDT have demonstrated the induction of cyclooxygenase-2 (COX-) expression via AP-1 and CRE activation through the $\mathrm{IP}_{3}-\mathrm{K} / \mathrm{Akt} / \mathrm{ERK}$, JNK, and p38 MAP kinase pathways in murine macrophages. It is known that induction of chronic inflammation is a common feature of tumor promotion [56]. In this sense, macrophages can promote cancer stem cells (CSCs) and can convert non-stem cells to CSCs $[67,68]$. It is now accepted that COX-2 is related to tumor promotion. This enzyme plays a key role in the inhibition of apoptosis, angiogenesis and the metastatic process. Although the mechanism of COX-2 up regulation is not fully understood, it could result from activation of Ras and the MAPK pathway. It has been recognized that protein kinase $\mathrm{B}(\mathrm{Akt} / \mathrm{PKB})$ activity is implicated in K-Ras-induced expression of COX-2 and the stabilization of COX-2 mRNA partially depends on the activation of Akt/PKB [69].

Activation of PKC $\alpha$ and $\delta$ was reported as one of the mechanisms that support the mitogenic effect of heptachlor in rat hepatocytes [70]. The ability of various OCs to stimulate PKC activity in vitro was also demonstrated [71]. Exposure to OCs has also been linked to an increased incidence of breast cancer disease. Boada et al. [72] evaluated the association of breast cancer and exposure to OCs mixtures and reported that breast cancer patients presented more frequently a combination of aldrin, p,p'-DDE and p,p'-DDD (dichloro diphenyldichloro ethane), while this mixture was not found in any healthy woman. Cohn et al. [73] conducted an epidemicological study and showed an association reinforced by a dose response relationship, between DDT exposure and development of breast cancer when exposure is prepuberal.

Experimental studies focusing on the discovery of genes that may be altered by pesticides may aid to complement the findings of epidemiological studies. Bratton et al. [74] studied gene expression in MCF-7 breast cancer cells after exposure to OC. These authors used either E2 or o,p'-DDT to identify distinct cellular gene expression responses. Both o,p'-DDT and E2 stimulated the transcription of a sub-set of ER $\alpha$-regulated genes and o,p'-DDT also up-regulated genes that were not affected by E2, including $V E G F$ (vascular endothelial growth factor). o,p'-DDT increased VEGFA expression in MCF7 cells, even in the presence of the pure antiestrogen ICI, suggesting that the o,p'-DDT effect is ER $\alpha$-independent. Moreover, using molecular and pharmacological techniques, these authors have investigated the role of MAPK pathways in the o,p'-DDT-CREB binding protein-hypoxia-inducible factor 1 signaling. Based in previous reports and in their findings they have proposed that o,p'-DDT-initiated ER-independent stimulation of gene expression and that o,p'-DDT has the ability to initiate crosstalk between p38 kinase and transcriptional coactivators. It must be highlighted that o,p'-DDT concentrations used in the experiments are similar to DDT metabolite levels reported in human blood $[75,76]$.

Experimental studies exploring the potential effects exerted by the mixtures of OC are scarce. Interestingly, Valerón et al. [77] have showed that the exposure of primary human mammary epithelial cells to an environmentally relevant mixture of OCs (p,p'-DDD plus p,p'DDE plus o,p'-DDE plus aldrin plus dieldrin) sharply up regulated the expression of a number of protein kinases genes, such as ACVRL1 (which correspondent protein is actively involved in mammary cell growth and morphogenesis), $A L K-1$ (which is expressed in different subtypes of human breast cancers) and $E R B B 3$ (a critical factor in the transformation process of ErbB2 in breast cancer cells), at concentrations close to those detected in human populations. Authors proposed a possible association between exposure to $\mathrm{OC}$ combinations and the induction of transformation processes in human breast cells.

Silva et al. [78] comparatively studied the effect profiles of E2, p,p'-DDE, o,p'-DDT and $\beta$-HCH by their ability to activate genomic and non-genomic events in MCF-7 breast cancer cells. Despite commonalities in their estrogenicity, as judged by cell proliferation assays, the environmental contaminants exhibited striking differences in their non-genomic and genomic signaling. The gene expression profiles of o,p'-DDT and $\beta-\mathrm{HCH}$ resembled the effects observed with E2.Transcription of $T F F 1$ (which expression increases with cell proliferation and tumor cell survival), $E R, P R$ (progesterone receptor) and $B R C A 1$ by E2, o,p'-DDT and $\beta$-HCH could be suppressed partially by inhibiting the $\mathrm{Src} / \mathrm{Ras} /$ Erk pathway.

Taken together the above findings, summarized in Table 1, strongly suggest association between OC phosphorylation pathways disruption and tumor development in several experimental systems.

Suggestive associations between OP use and chronic lymphocytic leukaemia [79] as well as cancers of the prostate were observed $[63,80]$.

In regards to experimental studies, a link among diacylglycerol (DAG) lipase, a known OP target, chlorpyrifos-oxon and ERK 44/42 activation in CHOK1 cells was proposed. Using specific inhibitors, it was shown that inhibition of DAG lipase by chlorpyrifos-oxon might lead to the accumulation of DAG, which in turn activates PKC, leading to sequential activation of MEK and ERK 44/42 [81].

Gwing et al. [82] studied gene expression in normal human mammary epithelial cells exposed to malathion. Interestingly, this experimental model was unable to assess interindividual variations in response to this OP. Cells exposition in concentrations producing minimal toxicity, decreased the expression in three of the four cell 
Table 1. Modulation of phosphorylation pathways involved in tumor development by organochlorine pesticides.

\begin{tabular}{|c|c|c|c|c|}
\hline Pesticide & Experimental system & Proteins/pathways/genes involved & Observed/proposed* effects & References \\
\hline $\begin{array}{l}\beta \text {-HCH, o,p'-DDT, } \\
\text { heptachlor epoxide }\end{array}$ & $\begin{array}{l}\text { Human prostate cancer } \\
\text { cell line LNCaP }\end{array}$ & erbB-2 kinase & Proliferative & [64] \\
\hline o,p'-DDT & $\begin{array}{l}\text { Human prostate cancer } \\
\text { cell line LNCaP }\end{array}$ & MAPK & Proliferative & [64] \\
\hline o,p'-DDT & Murine macrophages & $\begin{array}{l}\text { PI3-K/Akt/ERK, JNK, } \\
\text { and p38 MAPK }\end{array}$ & Increased $C O X-2$ gene expression & [66] \\
\hline Heptachlor & Hepatocytes & $\operatorname{PKC} \alpha, \operatorname{PKC} \delta$ & Mitogenic & [70] \\
\hline o,p'-DDT & MCF-7 breast cancer cells & p38 MAPK & $\begin{array}{l}\text { Gene expression profiles partially } \\
\text { resembled the effects observed } \\
\text { with E2.Increased } V E G F A \text { gene } \\
\text { expression }\end{array}$ & [74] \\
\hline $\mathrm{o}, \mathrm{p}$ '-DDT, $\beta$-HCH & $\begin{array}{l}\text { MCF- } 7 \text { cells breast } \\
\text { cancer cells }\end{array}$ & Src/Ras/Erk pathway & $\begin{array}{l}\text { Gene expression profiles } \\
\text { resembled the effects observed } \\
\text { with E2. Proliferative. }\end{array}$ & [78] \\
\hline $\begin{array}{l}\text { OCs mixture (p,p'-DDD plus } \\
\text { p,p'-DDE plus o,p'-DDE } \\
\text { plus aldrin plus dieldrin) }\end{array}$ & $\begin{array}{l}\text { Normal human mammary } \\
\text { epithelial cells }\end{array}$ & $\begin{array}{l}\text { protein kinases genes } \\
(A C V R L 1, A L K-1, K I T, \\
E R B B 3, \text { and } A C V R 1 C)\end{array}$ & $\begin{array}{l}\text { Increased gene expression. } \\
{ }^{*} \text { Potential induction of the } \\
\text { transformation processes }\end{array}$ & [77] \\
\hline
\end{tabular}

strains included, of three genes involved in the regulation and progression of the cell cycle, such as cyclin-dependent kinase inhibitor $(p 16 I N K 4 a)$, a protein involved in preventing anaphase promotion by disrupting cyclin $\mathrm{D} /$ CDK4 kinase complex [83]. In addition, malathion decreased the expression of six RNA species in all cell strains analyzed, including a putative mitotic checkpoint kinase $(B U B 1)$ [84], which is a core component of mitotic checkpoint. BUB1 kinase activity integrates attachment error correction and mitotic checkpoint signaling by controlling the localization and activity of Aurora B kinase, a highly conserved serine/threonine kinase that ensures accuracy of kinetochore-microtubule interacttions during mitosis, through phosphorylation of histone H2A $[84,85]$.

\subsection{Effects on Metabolic Signaling Pathways}

Despite intense investigations and the establishment of both preventive and therapeutic strategies, insulin resistance-associated metabolic diseases such as type 2 diabetes disorders have reached alarming proportions worldwide [86]. Although genetic predisposition and lifestyle choices are commonly accepted reasons for the occurrence of type 2 diabetes, it has recently been suggested that environmental pollutants are additional risk factors for diabetes development [87].

Several independent cross-sectional studies reported an association between type 2 diabetes and the body burdens of OC such as p,p'-DDE, oxychlordane, or transnonachlor $[88,89]$. A group of applicators who had used aldrin, chlordane, and heptachlor during more than 100 lifetime days had $51 \%, 63 \%$, and $94 \%$ increased odds of diabetes, respectively [90]. An experimental study of Ruzzin et al. [86] also supports these common findings. These authors studied the effects of persistent organic pollulants on insulin action in differentiated 3T3-L1 adipocytes through the ability of these cells to take up radioactive-labeled glucose in response to insulin. OCs were the most potent disruptors of insulin action of all the persistent organic pollulants mixtures tested in vitro. OC dramatically reduced the glucose uptake in differenttiated 3T3-L1 exposed adipocytes, suggesting alterations of the complex network of kinases/phosphatases involved in glucose uptake regulation by insuline.

Biologically plausible connections between OP and diabetes type 2 were also proposed; [90,91]. The majority of experimental studies in rats that have evaluated the effects of OP on glucose homeostasis have reported that exposure to OP induces hyperglycemia. It was also shown that impairments on glucose metabolism in the liver were associated to decreased glucokinase activity [92]. Stimulation of both glycogenolysis and gluconeogenesis, were also shown to take place via increased of glycogen phosphorylase and phosphoenolpyruvate carboxykinase activities respectively $[93,94]$. In an extensive review of experimental data Rezg et al. [91] proposed that transient hyperglycemia followed by compensatory insulinemia, may exhaust the metabolic control system, resulting in the loss of physiological response to insulin, leading to induction of diabetes type 2 .

The pancreas, that has a critical role in secretion of insulin, is also a target organ for pesticides toxicity. The activity and mRNA levels of pancreatic glucokinase, which is the flux-limiting glucose sensor in $\beta$-cells, was studied in OP exposition. Pancreatic glucokinase activity 
and expression were differently affected depending of the type of exposure and the OP used [92,94,95].

Type 2 diabetes is characterized by impaired insulin secretion. Hectors et al. [96] reviewed the mechanisms involved in the disruption of $\beta$ cell function by environmental pollutants. Studies showed higher insulin content but lower insulin secretion by islets isolated from malathion-treated rats. It was proposed that a malathionstimulated increase in $\mathrm{Ca}^{2+}$ levels could cause a functional loss of $\mathrm{Ca}^{2+} /$ calmodulin-dependent protein kinase, thereby decreasing $\mathrm{Ca}^{2+}$-induced insulin secretion. In addition, $\left[\mathrm{Ca}^{2+}\right]$ increase is also associated with apoptosis, another known effect of malathion (OP) in pancreatic cells.

\subsection{Effects on Inmune Signaling Pathways}

Cytokines are defined as a group of growth factors that bind to their cognate receptors and trigger intracellular signaling events that result in the modulation of gene expression. Interaction of a cytokine with its receptor rapidly induces tyrosine phosphorylation of the receptor and a variety of cellular cytokine receptors activation that mediate mitogenic and differentiation signals [97]. Alteration of immune system components and functions is related to the sequence and intensity of phosphorylation and dephosphorylation of protein kinases. These phosphorylation and dephosphorylation processes serve as an essential mechanism to control the functions of the immune system both when the host is exposed to an external pathogen and when the immune system recognizes self proteins [98].

Chronic exposure to OC has been suspected for causing immune regulatory abnormalities. In this sense, Dar et al. [99] studied the potential association among the OC blood levels with T-lymphocyte sub-sets and cytokine expression in patients with Systemic Lupus Erythematosus (SLE). Higher levels of p,p'-DDE and $\beta$-HCH were detected in the blood of SLE patients than in controls. Significant differences in T-lymphocyte subsets and cytokine expression were found among groups, suggesting in vivo exposure could lead to the development or exacerbation of SLE. However, no significant responsiveness of patient peripheral blood mononuclear cells to phytohemagglutinin-M stimulation was observed, indicating suppression of T-lymphocytes by these OC. Experimental studies to clarify altered pathways involved are still required.

Some reports indicate that OP pesticides can alter complement function, abundance of some leukocyte subpopulations, cell proliferation, cytokine secretion, surface marker expression, chemotaxis, phagocytosis, antigen presentation and apoptosis induction [100-102].

Many questions have emerged about the immunotoxic potential of OP compound metabolites mainly due to their longer half-life than their parental compound. In this sense several studies investigated the potential effects of OP metabolites such as dialkylphosphates (DAPs) and diethyldithiophosphate (DEDTP). It was reported that the exposure to some DAPs alters the proliferation induced by interleukin (IL)-2 in human lymphocytes. Specially, DEDTP modifies T CD4 lymphocyte IL-2 receptor-dependent proliferation by modifying the phosphorylation status of MAPKs and STAT5 proteins. Induction of the correct signal transduction pathway in $\mathrm{CD} 4+\mathrm{T}$ lymphocytes is essential for cellular processes like activation, clonal expansion, and control of the immune response. However, these processes are regulated by a feedback mechanism that is initiated when signals do not occur in the correct order or when signals are incomplete. A key source of this feedback is the suppressor of cytokine signaling 3 protein (SOCS3). This mechanism was disrupted by DEDTP. Increased phosphorylation of SOCS3 and dephosphorylation of STAT5 were induced after as little as $5 \mathrm{~min}$ of exposure. In addition, DEDTP induced phosphorylation of ERK, JNK and p38 and NFAT nuclear translocation, suggesting that DEDTP can modulate phosphorylation of intracellular proteins and may thus cause a failure in the response of $\mathrm{T}$ cells to further antigen challenges [98].

\subsection{Effects on Survival and Death Signaling Pathways}

Many pesticides share as a possible mechanism of toxicity, the ability to trigger apoptosis through alterations in redox homeostasis generated both by a decrease of antioxidant defenses and accumulation of reactive oxygen species (ROS) [103,104]. In general, pesticides have been shown to alter cellular redox balance by different mechanisms including: 1) their enzymatic conversion to secondary reactive products and/or ROS; 2) depletion of antioxidant defenses; and 3) the impairment of antioxidant enzyme function [104].

Increased ROS levels can induce the activation of survival responses such as up-regulation of antioxidant defenses [104-106]. The nuclear factor NF-kB, Keap1/ Nrf2, AP-1, phosphoinositide 3 kinase/Akt pathways, p53 heat shock proteins, and MAPK cascades are the main players discovered. These pathways operate in coordinated manner and several are critically important to cope with oxidative stress insults. They are Keap1/Nrf2, NF- $\kappa B$, Mapk and AP-1. At both, low and intermediate intensity oxidative stresses, MAP-kinases and other kinases are also involved in signal sensing and cellular response, leading to enhanced antioxidant potential. High intensity oxidative stress may overwhelm antioxidant potential and induce the opening of the mitochondrial 
permeability transition pore, a non-selective inner membrane permeabilization, that may proceed both to necrotic and apoptotic cell death [107].

Some OCs such as $\beta-\mathrm{HCH}$, and p,p'-DDE induced elevation of ROS and apoptotic effects in several systems. DDT derivatives have been shown to induce apoptosis through the activation of MAPKs in neural cell [108] and through oxidative stress-mediated p38 MAPK and mitochondria-related pathway in Sertoli cells [104].

It was also reported that lindane up-regulated classical PKCs gene expression by increasing oxidative stress in primary cultures of rat hepatocytes. PKCs up-regulation prevented the inhibition of spontaneous and intrinsic apoptosis pathway and induced necrotic cell death [109].

Numerous studies support the fact that OPs induce oxidative stress. The association of oxidative stress induced by OP with apoptosis have also been shown in different tissues $[110,111]$.

Considering that ROS generated by pesticides could be one of the factors underlying the pathogenesis of Parkinson's disease (PD), Lee et al. [112] studied the mechanism of chlorpyrifos-induced apoptotic cell death in cultured PC12 cells, a rat pheochromocytoma cell line as a model of dopaminergic neurons. Authors found that CPF activated MAPK pathways, including ERK 1/2, the JNK, and the p38 MAP kinase. It was also reported that JNK and p38 MAPK pathways might be critical mediators in chlorpyrifos-induced human neuroblastoma SHSY5Y apoptosis, not only by generating ROS but also by up-regulating COX-2 [113].

An elegant study of Liu et al. [114] revealed that MAPK signaling pathway is involved in the enantioselectivity of chiral pesticides. The (-) isocarbophos enantiomer, triggered the generation of intracellular ROS and sequentially induced sustainable activation of JNK, which in turn, resulted in the change of $\mathrm{Bax} / \mathrm{Bcl}-2$ ratio and the increase of cell apoptosis.

\subsection{Effects on Epigenetic Phosphorylation}

Epigenetic mechanisms are essential for development, cell differentiation, protection against viral genomes, and seem to be critical for the integration of endogenous and environmental signals during the life of a cell or an organism. By analogy, deregulation of epigenetic mechanisms has been associated with a variety of human diseases, most notably cancer [115]. Among epigenetic mechanisms, the covalent post-translational modifications of histone proteins are dependent on specific enzymes mechanism, which regulation is an active field of study [116]. Experimental evidence showed that the OP diazinon has been associated with cancer risks in humans by modifying the DNA methylation in promoter $\mathrm{CpG}$ sites of genes, many of which are carcinogenesis-related.
[117]. However, there is no information regarding pesticides effects on the phosphorylation of histones.

Major epigenetic events during spermiogenesis in many species, include the removal of nucleosomal histone proteins and their replacement by basic proteins called protamines. This histone-to-protamine exchange contributes to the extreme compaction of the genome in mature sperm. Recent studies show that this remarkable chromatin remodeling process might also contribute to the regulation of the embryonic transcriptional program after fertilization [118]. Once the DNA-protamine complex is formed, protamines are dephosphorylated before the sperm enter the epididymus to allow final chromatin condensation [119].

Considering the epidemiological associations of OP laboral exposure with sperm chromatin condensation alterations [120], Piña Guzmàn et al. [121] have evaluated the degree of sperm nuclear protein phosphorylation after diazinon exposure in rats. Interestingly, a significant increase in protamine phosphorylation was observed, which correlated with alterations in sperm chromatin structure parameters. These alterations would have implications for male fertility and, more importantly, exert detrimental effects on the development of the offspring if the damaged spermatozoa fertilize the egg.

\section{CHALLENGES}

The total number of phosphosites in the human proteome is predicted to exceed 650,000 , and over 100,000 of these phosphosites have already been experimentally confirmed in humans and/or related mammals. Phosphosites represent an excellent source of potential biomarkers for pesticides toxicity which should be further investigated. A key question in signal transduction proteins is that protein kinases are often present at 100- to 1000 -fold lower levels in cell lysate than structural proteins and metabolic pathway enzymes. Phosphorylation pathways may operate in a concerted manner and in most cases there is substantial interplay between their functions. The antibody microarray assay was developed as a research tool for large-scale profiling of hundreds and even thousands of proteins in a parallel fashion within a single sample and provides a fascinating window to high-throughput screening of pesticide toxicity. Moreover, the higher level of sensitivity of reverse-phase protein lysate microarrays which have been proved for their utilities in molecular profiling of phosphorylation events across large number of samples or their dynamics in response to various agents [13], hold a great potential to study large numbers of samples as those required in epidemiological studies or in the identification of unexpected phosphosite biomarkers. Phosphoproteome information can complement gene expression arrays re- 
sulting in a global approach to understanding the mechanisms involved in pesticide toxicology, by characterizing not only pesticides effects but also complex mixtures.

In regards to enzymes involved in phosphorylation pathways, major information available is concerning to kinases while there is a lack of information about phosphatases. Deciphering the mechanisms of pesticide's ability to interfere directly in kinases/phosphatases activity, is another important task. Up to date, there is scarce information of pesticide-protein interactions contributing to kinases/phosphatases activity disruption.

\section{CONCLUSION}

Phosphorylation pathways represent target toxicity of both persistent and rapidly metabolized and excreted pesticides. The above findings strengthen the view that pesticide-induced disruption in the phosphorylation pathways may contribute to the occurrence of reproductive, proliferative, metabolic and neurological adverse effects on humans. However, the effects observed in experimental models must be interpreted with caution, given their well-known limitations. Also, it is necessary to highlight that the doses tested in several in vitro studies were unrealistically high. By now, the potential impact of pesticides in epigenetic and immune phosphorylation pathways remains poorly explored. As humans are exposed to multiple pesticides, understanding the molecular events associated with pesticides exposure is complex. Microarray technology and studies of the mechanisms underlying phosphorylation disruption may provide the basis for defining new prevention and treatment strategies to improve human health.

\section{ACKNOWLEDGEMENTS}

The authors would like to thank Dra Mònica Montagna for the revision of the manuscript and the student Diego Potàs for designing the figure. The present work was supported by the Universidad Nacional de San Martin and the Universidad Nacional del Comahue.

\section{REFERENCES}

[1] Mostafalou, S. and Abdollahi, M. (2013) Pesticides and human chronic diseases: Evidences, mechanisms, and perspectives. Toxicology and Applied Pharmacology, 268, 157-177. http://dx.doi.org/10.1016/j.taap.2013.01.025

[2] Agrawi, A. and Sharma, B. (2010) Pesticides induced oxidative stress in mammalian systems. International Journal of Biological and Medical Research, 1, 90-104.

[3] Cohn, B., Cirillo, P. and Christianson, R. (2010) Prenatal DDT exposure and testicular Cancer: A nested case-control study. Archives of Environmental and Occupational Health, 65, 127-134. http://dx.doi.org/10.1080/19338241003730887

[4] Bouvier, G., Blanchard, O., Momas, I. and Seta, N. (2006)
Pesticide exposure of non-occupationally exposed subjects compared to some occupational exposure: A French pilot study. Science of the Total Environment, 366, 74-91. http://dx.doi.org/10.1016/j.scitotenv.2005.08.016

[5] Bouwman, H., van den Berg, H. and Kylin, H. (2011) DDT and malaria prevention: Addressing the paradox. Environmental Health Perspectives, 119, 744-747. http://dx.doi.org/10.1289/ehp.1002127

[6] Engeler, E. (2009) UN: Treaty Expanded by 9 more Dangerous Chemicals, The Guardian. http://www.guardian.co.uk/world/feedarticle/8498685

[7] Pathak, R., Mustafa, M.D., Ahmed, R., Tripathi, A., Guleria, K. and Banerjee, B.D. (2010) Association between recurrent Miscarriages and Organochlorine Pesticide Levels. Clinical Biochemistry, 43, 131-135.

http://dx.doi.org/10.1016/j.clinbiochem.2009.09.019

[8] Agrawal, A. and Sharma, B. (2010) Pesticide induced oxidative stress in mammalian system. A review. International Journal and Medical Research, 1, 90-104.

[9] Gwinn, M.R., Whipkey, D.L., Tennant, L.B. and Weston, A. (2005) Differential gene expression in normal human mammary epithelial cells treated with malathion monitored by DNA microarrays. Environmental Health Perspectives, 113, 1046-1051.

[10] Casida, J. and Quistad, G. (2004) Organophosphate Toxicology: Safety aspects of nonacetylcholinesterase seconddary targets. Chemical Research in Toxicology, 17, 983992. http://dx.doi.org/10.1021/tx0499259

[11] Sengupta, D., Wasim Aktar, M., Alam, S. and Chowdhury, A. (2010) Impact assessment and decontamination of pesticides from meat under different culinary processes. Earth and Environmental Science Environmental Monitoring and Assessment, 169, 37-43.

http://dx.doi.org/10.1007/s10661-009-1148-6

[12] Eaton, D.L., Daroff, R.B., Autrup, H., Bridges, J., Buffler, P., Costa, L.G. and Spencer, P.S. (2008) Review of the toxicology of chlorpyrifos with an emphasis on human exposure and neurodevelopment. Critical Reviews in Toxicology, 38, 1-125. http://dx.doi.org/10.1080/10408440802272158

[13] Zhang, H. and Pelech, S. (2012) Using protein microarrays to study phosphorylation-mediated signal transduction. Seminars in Cell \& Developmental Biology, 23, 872 882. http://dx.doi.org/10.1016/j.semcdb.2012.05.009

[14] Roskoski, R., Jr. (2012) ERK1/2 MAP kinases: Structure, function, and regulation. Pharmacological Research, 66, 105-143. http://dx.doi.org/10.1016/j.phrs.2012.04.005

[15] Marino, M., Pellegrini, M., La Rosa, P. and Acconcia, F. (2012) Susceptibility of estrogen receptor rapid responses to xenoestrogens: physiological outcomes. Steroids, 77, 910-917. http://dx.doi.org/10.1016/j.steroids.2012.02.019

[16] Swedenborg, E., Ruegg, J., Makela, S. and Pongratz, I. (2009) Endocrine disruptive chemicals: Mechanisms of action and involvement in metabolic disorders. Journal of Molecular Endocrinology, 43, 1-10. http://dx.doi.org/10.1677/JME-08-0132

[17] Fowler, P.A, Bellingham, M., Sinclair, K.D., Evans, N.P., Pocar, P., Fischer, B., Schaedlich, K., Schmidt, J.-S., 
Amezaga, M., R., Bhattacharya, S., Rhind, S.M. and O'Shaughnessy, P.J. (2012) Impact of endocrine-disrupting compounds (EDCs) on female reproductive health. Molecular and Cellular Endocrinology, 355, 231-239. http://dx.doi.org/10.1016/j.mce.2011.10.021

[18] Rogan, W. and Chen, A. (2005) Health risks and benefits of bis(4-chlorophenyl)-1,1,1-trichloroethene (DDT). Lancet, 366, 763-773. http://dx.doi.org/10.1016/S0140-6736(05)67182-6

[19] Tilghman, S.L., Nierth-Simpsonb, E. N.,Wallacec, R., Burowd, M.E. and Mc Lachlane, J.A. (2010) Environmental hormones: Multiple pathways for response may lead to multiple disease outcomes. Steroids, 75, 520-523. http://dx.doi.org/10.1016/j.steroids.2010.05.004

[20] Jeng, Y. and Watson C.-S. (2011) Combinations of physiologic estrogens with xenoestrogens alter ERK phosphorylation profiles in rat pituitary cells. Environmental Health Perspectives, 119, 104-112. http://dx.doi.org/10.1289/ehp.1002512

[21] Junttila, M.R., Li, S.-P. and Westermarck, J. (2008) Phosphatase-mediated crosstalk between MAPK signaling pathways in the regulation of cell survival. The FASEB Journal, 22, 4954-4965.

[22] Bulayeva, N. N. and Watson, C. S. (2004) Xenoestrogeninduced ERK-1 and ERK-2 activation via multiple membrane-initiated signaling pathways. Environmental Health Perspectives, 112, 1481-1487. http://dx.doi.org/10.1289/ehp.7175

[23] Li, X., Zhang, S., and Safe, S. (2006) Activation of kinase pathways in MCF-7cells by 17beta-estradiol and structurally diverse estrogenic compounds. The Journal of Steroid Biochemistry and Molecular Biology, 98, 122132. http://dx.doi.org/10.1016/j.jsbmb.2005.08.018

[24] Liu, J., Zhao, M., Zhuang, S., Yang, Y., Yang, Y., et al. (2012) Low concentrations of o,p'-DDT inhibit gene expression and prostaglandin synthesis by estrogen receptor-independent mechanism in rat ovarian cells. PLoS ONE, 7, e49916.

[25] Korrick, S.A., Chen, C., Damokosh, A.W., Ni, J., Liu, X., Sung, I.C., Altshul, L., Ryan L. and Xu, X. (2001) Association of DDT with spontaneous abortion: A case-control study. Annals of Epidemiology, 11, 491-496. http://dx.doi.org/10.1016/S1047-2797(01)00239-3

[26] Longnecker, M.,P., Klebanoff, M.A., Zhoo, H. and Bruck, J.W. (2001) Association between maternal serum concentration of the DDT metabolite DDE and preterm and small for gestational age babies at birth. Lancet, 358, 110-114. http://dx.doi.org/10.1016/S0140-6736(01)05329-6

[27] Delidaki, M, Gu, M., Hein, A., Vatish, M. and Grammatopoulos, D.K. (2011) Interplay of cAMP and MAPK pathways in hCG secretion and fusogenic gene expression in a trophoblast cell line. Molecular and Cellular Endocrinology, 332, 213-320. http://www.ncbi.nlm.nih.gov/pubmed/21035520

[28] Gomez-Concha, C., Flores-Herrera, O., Olvera-Sanchez, S., Espinosa-Garcia, M.T. and Martinez, F. (2011) Progesterone synthesis by human placental mitochondria is sensitive to PKA inhibition by H89. International Jour- nal of Biochemistry and Cell Biology, 43, 1402-1411. http://dx.doi.org/10.1016/j.biocel.2011.06.005

[29] Magnarelli, G., Souza, M.S and P. de D' Angelo and A.M. (2009) Heptachlor and op'DDT effects on protein kinase activities associated with human placenta particulated fractions. Biochemical and Molecular Toxicology, 23, 185-192. http://dx.doi.org/10.1002/jbt.20277

[30] Maldonado-Mercado, M., Espinosa-Garc'1a, M.T., Cuauht'emoc, G.-C., Monreal-Flores, J. and Martinez, F. (2008) Steroidogenesis in BeWo cells: Role of protein kinase A and benzodiazepines. International Journal of Biochemistry and Cell Biology, 40, 901-908. http://dx.doi.org/10.1016/j.biocel.2007.10.026

[31] Ridano, M.E., Racca, A.C., Flores-Martín, J., Camolotto, S.A., Magnarelli de Potas, G.M., Genti-Raimondi, S. and Panzetta-Dutari, G.M. (2012) Chlorpyrifos modifies the expression of genes involved in human placental function. Reproductive Toxicology, 33, 331-338. http://dx.doi.org/10.1016/j.reprotox.2012.01.003

[32] Dimon-Gadal, S., Gerbaud, P., Keryer, G., Anderson, W., Evain-Brion, D. and Raynaud, F. (1998) In vitro effects of oxygen derived free radicals on type I and type II cAMPdependent protein kinases. Journal of Biological Chemistry, 273, 22833-22840. http://dx.doi.org/10.1074/jbc.273.35.22833

[33] Grünfeld, H.T. and Bonefeld-Jorgensen, E.C. (2004). Effect of in vitro estrogenic pesticides on human oestrogen receptor alpha and beta mRNA levels. Toxicology Letters, 151, 467-480. http://dx.doi.org/10.1016/j.toxlet.2004.03.021

[34] Ventura, C., Núñez, M.,, Miretb, N., Martinel Lamasa, D., Randib, A., Venturino, A., Rivera, E. and Cocca, C. (2012) Differential mechanisms of action are involved in chlorpyrifos effects in estrogen-dependent or -independent breast cancer cells exposed to low or high concentrations of the pesticide. Toxicology Letters, 213, 184-193. http://dx.doi.org/10.1016/j.toxlet.2012.06.017

[35] Tamura, H., Maness, S.C., Reischmann, K., Dorman, D.C., Gray, L.E. and Gaido, K.W. (2001) Androgen receptor antagonism by the organophosphate insecticide fenitrothion. Toxicological Sciences, 60, 56-62. http://dx.doi.org/10.1093/toxsci/60.1.56

[36] Kojima, H., Katsura, E., Takeuchi, S., Niiyama, K. and Kobayashi, K. (2004) Screening for estrogen and androgen receptor activities in 200 pesticides by in vitro reporter gene assays using Chinese hamster ovary cells. Environmental Health Perspectives, 112, 524-531. http://dx.doi.org/10.1289/ehp.6649

[37] Sánchez, J.C., López-Zapata, D.F., Francis, L. and de los Reyes, L. (2011) Effects of estradiol and IGF-1 on the sodium calcium exchanger in rat cultured cortical neurons. Cellular and Molecular Neurobiology, 31, 619-627. http://dx.doi.org/10.1007/s10571-011-9657-6

[38] Fiocchetti, M., Ascenzi, P. and Marino, M. (2012) Neuroprotective effects of $17 \beta$-estradiol rely on estrogen receptor membrane initiated signals. Frontiers in Physiology, 3, 73. http://dx.doi.org/10.3389/fphys.2012.00073

[39] Hedges, V.L., Ebner, T.J., Meisel, R.L. and Mermelstein, P.G. (2012) The cerebellum as a target for estrogen action. 
Frontiers in Neuroendocrinology, 33, 403-411.

[40] Yamagata, Y., Kanekoc, K., Kasea, D., Ishihara, H., Nairne, A.C., Obatac, K. and Yakamata, I. (2013) Regulation of ERK1/2 mitogen-activated protein kinase by NMDA-receptor-induced seizure activity in cortical slices. Brain Research, 1507, 1-10.

http://www.ncbi.nlm.nih.gov/pubmed/23419897 http://dx.doi.org/10.1016/j.brainres.2013.02.015

[41] Kapfhammer, J. P. (2004) Cellular and molecular control of dendritic growth and development of cerebellar purkinje cells. Progress in Histochemistry and Cytochemistry, 39, 131-182. http://dx.doi.org/10.1016/j.proghi.2004.07.002

[42] Lonze, E. and Ginty, D.D. (2002) Function and regulation of CREB family transcription factors in the nervous system. Neuron, 3, 605-623.

[43] Briz, V., Molina-Molina, J.M., Sánchez-Redondo, S., Fernández, M.F., Grimalt, J.O., Olea, N. and Suñol, C. (2011) Differential estrogenic effects of the persistent organochlorine pesticides dieldrin, endosulfan, and lindane in primary neuronal cultures. Toxicological Sciences, 120, 413-427. http://dx.doi.org/10.1093/toxsci/kfr019

[44] Fleming, L., Mann, J.B., Bean, J., Briggle, T. and Sanchez-Ramos, J.R. (1994) Parkinson's disease and brain levels of organochlorine pesticides. Annals of Neurology, 36, 100-103. http://dx.doi.org/10.1002/ana.410360119

[45] Corrigan, F.M., Wienburg, C.L., Shore, R.F., Daniel, S.E. and Mann, D. (2000) Organochlorine insecticides in substantia nigra in Parkinson's disease. Journal of Toxicology and Environmental Health A, 59, 229-234. http://dx.doi.org/10.1080/009841000156907

[46] Wang, G., Pan, J. and Chen, S.D. (2012) Kinases and kinase signaling pathways: Potential therapeutic targets in Parkinson's disease. Progress in Neurobiology, 98, 207221. http://dx.doi.org/10.1016/i.pneurobio.2012.06.003

[47] Niijima, H., Nagao, M., Nakajima, M., Takatori, T., Matsuda, Y., Iwase, H. and Kobayashi, M. (1999) Sarin-like and soman-like organophosphorous agents activate PLC gamma in rat brains. Toxicology and Applied Pharmacology, 156, 64-69. http://dx.doi.org/10.1006/taap.1998.8628

[48] Schuh, R.A., Lein, P.J., Beckles, R.A. and Jet, D.A. (2002) Noncholinesterase mechanisms of chlorpyrifos neurotoxicity: Altered phosphorylation of $\mathrm{Ca}^{2+} / \mathrm{cAMP}$ response element binding protein in cultured neurons. Toxicology and Applied Pharmacology, 182, 176-185. http://dx.doi.org/10.1006/taap.2002.9445

[49] Slotkin, T.A. and Seidler, F.J. (2009) Protein kinase C is a target for diverse developmental neurotoxicants: Transcriptional responses to chlorpyrifos, diazinon, dieldrin and divalent nickel in PC12 cells. Brain Research, 263, 23-32. http://dx.doi.org/10.1016/j.brainres.2009.01.049

[50] Moreira, E.G., Xiaozhong, Y., Robinson, J.F., Griffith, W., Woo Hong, S., Beyer, R.P., Bammler, T.K. and Faustman, E.M. (2010) Toxicogenomic profiling in maternal and fetal rodent brains following gestational exposure to chlorpyrifos. Toxicology and Applied Pharmacology, 245, 310-325. http://dx.doi.org/10.1016/j.taap.2010.03.015

[51] Jett, D.A., Navoa, R.V., Beckles, R.A. and McLemore, G.L. (2001) Cognitive function and cholinergic neurochemistry in weanling rats exposed to chlorpyrifos. Toxicology and Applied Pharmacology, 174, 89-98. http://dx.doi.org/10.1006/taap.2001.9198

[52] Rohlman, D.S., Lasarev, M., Anger, W.K., Scherer, J., Stupfel, J. and McCauley, L. (2007) Neurobehavioral performance of adult and adolescent agricultural workers. Neurotoxicology, 28, 374-380.

http://dx.doi.org/10.1016/j.neuro.2006.10.006

[53] Canadas, F., Cardona, D., Davila, E. and Sanchez-Santed, F. (2005) Long-term neurotoxicity of chlorpyrifos: Spatial learning impairment on repeated acquisition in a water maze. Toxicologycal Sciences, 85, 944-951. http://dx.doi.org/10.1093/toxsci/kfi143

[54] Verma, S.K., Geetu, R. and Gil, K.D. (2009) Role of muscarinic signal transduction and CREB phosphorylation in dichlorvos-induced memory deficits in rats: An acetylcholine independent mechanism. Toxicology, 256, 175-182. http://dx.doi.org/10.1016/j.tox.2008.11.017

[55] RamaRao, G., Acharya, N.J. and Bhattacharya, B.K. (2011) Changes of protein oxidation, calpain and cytoskeletal proteins (alpha tubulin and $\mathrm{pNF}-\mathrm{H}$ ) levels in rat brain after nerve agent poisoning .Toxicology Letters, 203, 227-236. http://dx.doi.org/10.1016/j.toxlet.2011.03.020

[56] Rundhaug, J.E. and Fischer, S.M. (2010) Molecular mechanisms of mouse skin tumor promotion. Cancers, 2, 436-482. http://dx.doi.org/10.3390/cancers2020436

[57] Terman, B. and Stoletov, K.V. (2001) VEGF and tumor angiogenesis. The Einstein Quarterly Journal of Biology and Medicine, 18, 59-66.

[58] Bharathi, S.P., Raj, H.M., Jain, S., Banerjee, B.D., Ahmed, T. and Arora, V.K. (2013) Role of pesticides in the induction of tumor angiogenesis. Anticancer Research, 33, 231-240.

[59] Hreljac, I., Zajc, I., Lah, T. and Filipic, M. (2008) Effects of model organophosphorous pesticides on DNA damage and proliferation of HepG2 cells. Environmental and Molecular Mutagenesis, 49, 360-367.

http://dx.doi.org/10.1002/em.20392

[60] Vakonaki, E., Androutsopoulos, V.P., Liesivuori, J., Tsatsakis, A.M. and Spandidos, D.A. (2013) Pesticides and oncogenic modulation. Toxicology, 307, 42-45.

http://www.ncbi.nlm.nih.gov/pubmed/23354457 http://dx.doi.org/10.1016/j.tox.2013.01.008

[61] Griner, E.M. and Kazanietz, M.G. (2007) Protein kinase $\mathrm{C}$ and other diacylglycerol effectors in cancer. Nature Reviews Cancer, 7, 281-294.

http://dx.doi.org/10.1038/nrc2110

[62] Mrema, E.J., Rubino, F.M., Brambilla, G., Moretto, A., Tsatsakis, A.M. and Colosio, C. (2013) Persistent organochlorinated pesticides and mechanisms of their toxicity. Toxicology, 307, 74-88.

http://dx.doi.org/10.1016/j.tox.2012.11.015

[63] Koutros, S., Freeman, L.E.B., Lubin, J.H., Heltshe, S.L., Andreotti, G., Barry, K.H. and Alavanja, M.C. (2013) Risk of total and aggressive prostate cancer and pesticide 
use in the agricultural health study. American Journal of Epidemiology, 177, 59-74.

http://dx.doi.org/10.1093/aje/kws225

[64] Cockburn, M., Mills, P., Zhang, X., Zadnick, J., Goldberg, D. and Ritz, B. (2011) Prostate cancer and ambient pesticide exposure in agriculturally intensive areas in California. American Journal of Epidemiology, 173, 1280-1288. http://dx.doi.org/10.1093/aje/kwr003

[65] Tessier, D.M. and Matsumura, F. (2001) Increased ErbB2 tyrosine kinase activity, MAPK phosphorylation, and cell proliferation in the prostate cancer cell line $\mathrm{LNCaP}$ following Treatment by Select Pesticides. Toxicological Science, 60, 38-43.

http://dx.doi.org/10.1093/toxsci/60.1.38

[66] Han, E.-H., Kim J.Y., Kim, H.-K., Hwang Y.P. and Jeong, H.G. (2008) O,p'-DDT induces cyclooxygenase-2 gene expression in murine macrophages: Role of AP-1 and CRE promoter elements and PI3-kinase/Akt /MAPK signaling pathways. Toxicology and Applied Pharmacology, 233, 333-342.

http://dx.doi.org/10.1016/j.taap.2008.09.003

[67] Iliopoulos, D., Hirsch, H.A., Wang, G. and Struhl, K. (2011) Inducible formation of breast cancer stem cells and their dynamic equilibrium with non-stem cancer cells via IL6 secretion. Proceedings of the National Academy of Sciences of the United States of America, 108, 13971402. http://dx.doi.org/10.1073/pnas.1018898108

[68] Kuraishy, A., Karin, M. and Grivennikov, S. (2011) Tumor promotion via injury and death-induced inflammation. Immunity, 35, 467-477.

http://dx.doi.org/10.1016/j.immuni.2011.09.006

[69] Gosh, N., Chaki, R., Mandal, V. and Mandal, S. (2010) COX-2 as a target for cancer chemotherapy. Pharmacologycal Reports, 62, 233-244.

[70] Okoumassoun, L.E, Averill-Bates, D., Marion, M. and Denizeau. F. (2003) Possible mechanisms underlying the mitogenic action of heptachlor in rat hepatocytes. Toxicology and Applied Pharmacology, 193, 356-369.

[71] Bagchi, D., Bagchi, M., Tang, L. and Stohs, S.J. (1997) Comparative in vitro and in vivo protein kinase $\mathrm{C}$ activation by selected pesticides and transition metal salts. Toxicology Letters, 91, 31-37. http://dx.doi.org/10.1016/S0378-4274(97)03868-X

[72] Boada, L.D, Zumbado, M., Henríquez-Hernández, L.A, Almeida-González, M., Álvarez-León, E.E., Serra-Majem, L. and Luzardo, O.P (2012) Complex organochlorine pesticide mixtures as determinant factor for breast cancer risk: A population-based case-control study in the Canary Islands (Spain). Environmental Health, 11, 1-9.

[73] Cohn, B.A., Wolff, M.S., Cirillo, P.M. and Sholtz, R.I. (2007) DDT and breast cancer in young women: New data on the significance of age at exposure. Environmental Health Perspectives, 115, 1406-1414.

[74] Bratton, M.R., Frigo, D.E., Segar, C., Nephew, K.P., McLachlan, J.A., Wiese, T.E. and Burow, M.E. (2012) The organochlorine $\mathrm{o}, \mathrm{p}^{\prime}$-DDT plays a role in coactivator-mediated MAPK crosstalk in MCF-7 breast cancer cells. Environmental Health Perspectives, 120, 1291-1296. http://dx.doi.org/10.1289/ehp.1104296
[75] Longnecker, M.P., Klebanoff, M.A., Brock, J.W., Zhou, H., Gray, K.A., Needham, L.L., et al. (2002) Maternal serum level of 1,1-dichloro-2,2-bis ( $p$-chlorophenyl) ethylene and risk of cryptorchidism hypospadias, and polythelia among male offspring. American Journal of Epidemiology, 155, 313-322. http://dx.doi.org/10.1093/aje/155.4.313

[76] López-Carrillo, L., Torres-Sánchez, L., Moline, J., Ireland, K. and Wolff, M.S. (2001) Breast-feeding and serum $p$, $p$ DDT levels among Mexican women of childbearing age: A pilot study. Environmental Research, 87, 131-135. http://dx.doi.org/10.1006/enrs.2001.4296

[77] Valerón, P.F., Pestano, J.J., Luzardo, O.P., Zumbado, M.L., Almeida, M. and Boada, L.D. (2009) Differential effects exerted on human mammary epithelial cells by environmentally relevant organochlorine pesticides either individually or in combination. Chemico-Biological Interactions, 180, 485-491. http://dx.doi.org/10.1016/j.cbi.2009.04.010

[78] Silva, E., Kabil, A. and Kortenkamp, A. (2010) Crosstalk between non-genomic and genomic signalling pathways - distinct effect profiles of environmental estrogens. Toxicology and Applied Pharmacology, 245, 160170. http://dx.doi.org/10.1016/j.taap.2010.02.015

[79] Cocco, P., Satta, G., Dubois, S., Pili, C., Pilleri, M., Zucca, M. and Boffetta, P. (2013) Lymphoma risk and occupational exposure to pesticides: Results of the epilymph study. Occupational and Environmental Medicine, 70, 91-98. http://dx.doi.org/10.1136/oemed-2012-100845

[80] Bonner, M.R., Williams, B.A., Rusiecki, J.A., Blair, A., Freeman, L.E.B., Hoppin, J.A. and Alavanja, M.C. (2010) Occupational exposure to terbufos and the incidence of cancer in the agricultural health study. Cancer Causes \& Control, 21, 871-877. http://dx.doi.org/10.1007/s10552-010-9514-9

[81] Bomser, J.A., Quistad, G.B. and Casida, J.E. (2002). Chlorpyrifos oxon potentiates diacylglycerol-induced extracellular signal-regulated kinase (ERK 44/42) activation, possibly by diacylglycerol lipase inhibition. Toxicology and Applied pharmacology, 178, 29-36. http://dx.doi.org/10.1006/taap.2001.9324

[82] Gwinn, M.R., Whipkey, D.L., Tennant, L.B. and Weston, A. (2005) Differential gene expression in normal human mammary epithelial cells treated with malathion monitored by DNA microarrays. Environmental Health Perspectives, 113, 1046-1051. http://dx.doi.org/10.1289/ehp.7311

[83] Smeds, J., Berggren, P., Ma, X., Xu, Z., Hemminki, K., and Kumar, R. (2002) Genetic status of cell cycle regulators in squamous cell carcinoma of the oesophagus: The $C D K N 2 A\left(p 16^{(\mathrm{INK} 4 a)}\right.$ and $\left.p 14^{(A R F)}\right)$ and $p 53$ genes are major targets for inactivation. Carcinogenesis, 23, 645-655. http://dx.doi.org/10.1093/carcin/23.4.645

[84] Suijkerbuijk, S.J., Vleugel, M., Teixeira, A. and Kops, G.J. (2012) Integration of kinase and phosphatase activeties by BUBR1 ensures formation of stable kinetochoremicrotubule attachments. Developmental Cell, 23, 745755. http://dx.doi.org/10.1016/j.devcel.2012.09.005

[85] Ricke, R.M. and van Deursen, J.M. (2011) Correction of 
microtubule-kinetochore attachment errors: Mechanisms and role in tumor suppression. Seminars in Cell \& Developmental Biology, 22, 559-565. http://dx.doi.org/10.1016/j.semcdb.2011.03.007

[86] Ruzzin, J., Petersen, R., Meugnier, E., Madsen, L., Lock, E.J., Lillefosse, H. and Frøyland, L. (2010) Persistent organic pollutant exposure leads to insulin resistance syndrome. Environmental Health Perspectives, 118, 465-471.

[87] Wu, H., Bertrand, K.A., Choi, A.L., Hu, F.B., Laden, F., Grandjean, P. and Sun, Q. (2013) Persistent organic pollutants and type 2 diabetes: A prospective analysis in the nurses' health study and meta-analysis. Environmental Health Perspectives, 121, 153-161.

[88] Rignell-Hydbom, A., Rylander, L. and Hagmar, L. (2007) Exposure to persistent organochlorine pollutants and type 2 diabetes mellitus. Human and Experimental Toxicology, 26, 447-452. http://dx.doi.org/10.1177/0960327107076886

[89] Turyk, M., Anderson, H.A., Knobeloch, L., Imm, P. and Persky, V.W. (2009) Prevalence of diabetes and body burdens of polychlorinated biphenyls, polybrominated diphenyl ethers, and $p, p^{\prime}$-diphenyldichloroethene in Great Lakes sport fish consumers. Chemosphere, 75, 674-679. http://dx.doi.org/10.1016/j.chemosphere.2008.12.035

[90] Montgomery, M.P., Kamel, F., Saldana, T.M., Alavanja, M.C.R. and Sandler, D.P. (2008) Incident diabetes and pesticide exposure among licensed pesticide applicators: Agricultural health study, 1993-2003. American Journal of Epidemiology, 167, 1235-1246. http://dx.doi.org/10.1093/aje/kwn028

[91] Rezg, R., Mornagui, B., El-Fazaa, S. and Gharbi, N. (2010) Organophosphorus pesticides as food chain contaminants and type 2 diabetes: A review. Trends in Food Science \& Technology, 2, 345-357. http://dx.doi.org/10.1016/j.tifs.2010.04.006

[92] Romero-Navarro, G., Lopez-Aceves, T., Rojas-Ochoa, A., and Fernandez Mejia, C. (2006) Effect of dichlorvos on hepatic and pancreatic glucokinase activity and gene expression, and on insulin mRNA levels. Life Sciences, 78, 1015-1020. http://dx.doi.org/10.1016/j.1fs.2005.06.010

[93] Rahimi, R. and Abdollahi, M. (2007) A review on the mechanisms involved in hyperglycemia induced by organophosphorus pesticides. Pesticide Biochemistry and Physiology, 88, 115-121. http://dx.doi.org/10.1016/j.pestbp.2006.10.003

[94] Karami-Mohajeri, S. and Abdollahi, M. (2011) Toxic influence of organophosphate, carbamate, and organochlorine pesticides on cellular metabolism of lipids, proteins, and carbohydrates: A systematic review. Human \& Experimental Toxicology, 30, 1119-1140. http://dx.doi.org/10.1177/0960327110388959

[95] Panahi, P., Vosough-Ghanbari, S., Pournourmohammadi, S., Ostad, S.N., Nikfar, S., Minaie, B. and Abdollahi, M. (2006) Stimulatory effects of malathion on the key enzymes activities of insulin secretion in langerhans islets, glutamate dehydrogenase and glucokinase. Toxicology Mechanisms and Methods, 16, 161-167. http://dx.doi.org/10.1080/15376520500191623

[96] Hectors, T.L.M., Vanparys, C., van der Ven, K., Martens,
G.A., Jorens, P.G., Van Gaal, L.F. and Blust, R. (2011) Environmental pollutants and type 2 diabetes: A review of mechanisms that can disrupt beta cell function. Diabetologia, 54, 1273-1290.

http://dx.doi.org/10.1007/s00125-011-2109-5

[97] Jatiani, S.S., Baker, S.J., Silverman, L.R. and Reddy, E.P. (2010) JAK/STAT pathways in cytokine signaling and myeloproliferative disorders approaches for targeted therapies. Genes \& Cancer, 1, 979-993.

http://dx.doi.org/10.1177/1947601910397187

[98] Esquivel-Sentíes, M.S., Barrera, I., Ortega, A. and Vega, L. (2010) Organophosphorous pesticide metabolite (DEDTP) induces changes in the activation status of human lymphocytes by modulating the interleukin 2 receptor signal transduction pathway. Toxicology and Applied Pharmacology, 248, 122-133. http://dx.doi.org/10.1016/j.taap.2010.07.017

[99] Dar, S.A., Das, S., Ramachandran, V.G., Bhattacharya, S.N., Mustafa, M.D., Banerjee, B.D. and Verma, P. (2012) Alterations in T-lymphocyte sub-set profiles and cytokine secretion by PBMC of systemic lupus erythematosus patients upon in vitro exposure to organochlorine pesticides. Journal of Immunotoxicology, 9, 85-95. http://dx.doi.org/10.3109/1547691X.2011.642103

[100] Duramad, P., Tager, I.B., Leikauf, J., Eskenazi, B. and Holland, N.T. (2006) Expression of Th1/Th2 cytokines in human blood after in vitro treatment with chlorpyrifos, and its metabolites, in combination with endotoxin LPS and allergen Der $p 1$. Journal of Applied Toxicology, 26, 458-465. http://dx.doi.org/10.1002/jat.1162

[101] Li, Q. (2007) New mechanism of organophosphorus pesticide-induced immunotoxicity. Journal of Nippon Medical School, 74, 92-105. http://dx.doi.org/10.1272/jnms.74.92

[102] Esquivel-Sentíes, M.S. and Vega, L. (2012) Organophosphorous pesticides metabolite reduces human T CD8 homeostasis and proliferation by inducing cellular death. Journal of Environmental \& Analytical Toxicology.

[103] Elsharkawy, E.E., Yahia, D. and El-Nisr, N.A. (2013) Sub-chronic exposure to chlorpyrifos induces hematological, metabolic disorders and oxidative stress in rat: Attenuation by glutathione. Environmental Toxicology and Pharmacology, 35, 218-227. http://dx.doi.org/10.1016/j.etap.2012.12.009

[104] Franco, R., Sánchez-Olea, R., Reyes-Reyes, E.M. and Panayiotidis, M.I. (2009) Environmental toxicity, oxidative stress and apoptosis: Menage a trois. Mutation Research/ Genetic Toxicology and Environmental Mutagenesis, 674, 3-22. http://dx.doi.org/10.1016/j.mrgentox.2009.01.005

[105] Limón-Pacheco, J. and Gonsebatt, M.E. (2009) The role of antioxidants and antioxidant-related enzymes in protective responses to environmentally induced oxidative stress. Mutation Research/Genetic Toxicology and Environmental Mutagenesis, 674, 137-147. http://dx.doi.org/10.1016/j.mrgentox.2008.09.015

[106] Song, M.O., Lee, C.H., Yang, H.O. and Freedman, J.H. (2012). Endosulfan upregulates AP-1 binding and AREmediated transcription via ERK1/2 and p38 activation in HepG2 cells. Toxicology, 292, 23-32. 
http://dx.doi.org/10.1016/j.tox.2011.11.013

[107] Lushchak, V.I. (2011) Adaptive response to oxidative stress: Bacteria, fungi, plants and animals. Comparative Biochemistry and Physiology Part C: Toxicology \& Pharmacology, 153, 175-190. http://dx.doi.org/10.1016/j.cbpc.2010.10.004

[108] Mrema, E.J., Rubino, F.M., Brambilla, G., Moretto, A., Tsatsakis, A.M. and Colosio, C. (2013) Persistent organochlorinated pesticides and mechanisms of their toxicity. Toxicology, 307, 74-88. http://dx.doi.org/10.1016/j.tox.2012.11.015

[109] Zucchini-Pascal, N., de Sousa, G., Pizzol, J. and Rahmani, R. (2011) Molecular investigation of the effects of lindane in rat hepatocytes: Microarray and mechanistic studies. Food and Chemical Toxicology, 49, 3128-3135. http://dx.doi.org/10.1016/j.fct.2011.09.033

[110] Ojha, A., Yaduvanshi, S.K. and Srivastava, N. (2011) Effect of combined exposure of commonly used organophosphate pesticides on lipid peroxidation and antioxidant enzymes in rat tissues. Pesticide Biochemistry and Physiology, 99, 148-156. http://dx.doi.org/10.1016/j.pestbp.2010.11.011

[111] Uchendu, C.H., Ambali, S.F. and Ayo, J.O. (2012) The organophpsphate, chlorpyrifos, oxidative stress and the role of some antioxidants: A review. African Journal of Agricultural Research, 7, 2720-2728.

[112] Lee, J.E., Park, J.H., Shin, I.C. and Koh, H.C. (2012) Reactive oxygen species regulated mitochondria-mediated apoptosis in PC12 cells exposed to chlorpyrifos. Toxicology and Applied Pharmacology, 63, 148-162. http://dx.doi.org/10.1016/j.taap.2012.06.005

[113] Ki, Y.W., Park, J.H., Lee, J.E., Shin, I.C. and Koh, H.C. (2013) JNK and p38 MAPK regulate oxidative stress and the inflammatory response in chlorpyrifos-induced apoptosis. Toxicology Letters, 218, 235-245. http://dx.doi.org/10.1016/j.toxlet.2013.02.003

[114] Liu, H., Liu, J., Xu, L., Zhou, S., Li, L. and Liu, W. (2010) Enantioselective cytotoxicity of isocarbophos is mediated by oxidative stress-induced JNK activation in human hepatocytes. Toxicology, 276, 115-121. http://dx.doi.org/10.1016/j.tox.2010.07.018

[115] Vaissière, T., Sawan, C. and Herceg, Z. (2008) Epigenetic interplay between histone modifications and DNA methylation in gene silencing. Mutation Research/Reviews in Mutation Research, 659, 40-48. http://dx.doi.org/10.1016/j.mrrev.2008.02.004

[116] Bannister, A.J. and Kouzarides, T. (2011) Regulation of chromatin by histone modifications. Cell Research, 21, 381-395. http://dx.doi.org/10.1038/cr.2011.22

[117] Zhang, X., Wallace, A.D., Du, P., Lin, S., Baccarelli, A.A., Jiang, H. and Hou, L. (2012) Genome-wide study of DNA methylation alterations in response to Diazinon exposure in vitro. Environmental Toxicology and Pharmacology, 343, 959-968. http://dx.doi.org/10.1016/j.etap.2012.07.012

[118] Kota, S.K. and Feil, R. (2010) Epigenetic transitions in germ cell development and meiosis. Developmental Cell, 19, 675-686. http://dx.doi.org/10.1016/j.devcel.2010.10.009

[119] Oliva, R. and Dixon, G.H. (1991) Vertebrate protamine genes and the histone to protamine replacement reaction. Progress in Nucleic Acid Research and Molecular Biology, 40, 25-94. http://dx.doi.org/10.1016/S0079-6603(08)60839-9

[120] Sánchez-Peña, L.C., Reyes, B.E., López-Carrillo, L., Recio, R., Morán-Martínez, J., Cebrián, M.E. and QuintanillaVega, B. (2004) Changes on sperm chromatin structure in organophosphorus agricultural workers. Toxicology and Applied Pharmacology, 196, 108-113. http://dx.doi.org/10.1016/j.taap.2003.11.023

[121] Piña-Guzmán, B., Solis-Heredia, M.J. and QuintanillaVega, B. (2005) Diazinon alters sperm chromatin structure in mice by phosphorylating nuclear protamines. Toxicology and Applied Pharmacology, 202, 189-198. http://dx.doi.org/10.1016/j.taap.2004.06.028 